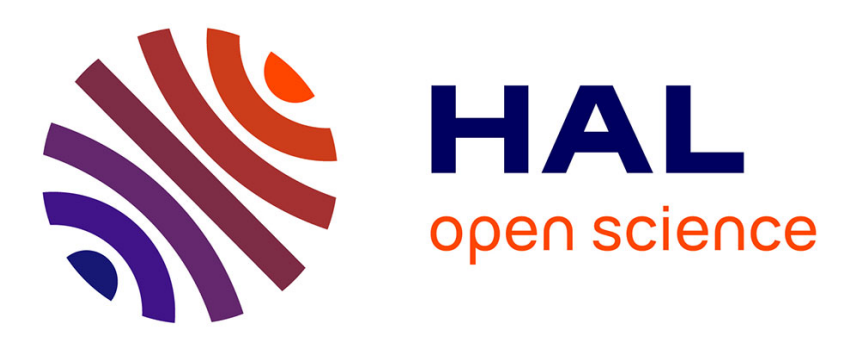

\title{
Geochemical records of limestone façades exposed to urban atmospheric contamination as monitoring tools?
}

Fabrice Monna, A Puertas, Francois Leveque, R. Losno, G. Fronteau, B Marin, J Dominik, Christophe Petit, B Forel, C Chateau

\section{- To cite this version:}

Fabrice Monna, A Puertas, Francois Leveque, R. Losno, G. Fronteau, et al.. Geochemical records of limestone façades exposed to urban atmospheric contamination as monitoring tools?. Atmospheric Environment, 2008, 42, pp.999 - 1011. hal-02569556

\section{HAL Id: hal-02569556 https://hal.science/hal-02569556}

Submitted on 19 May 2020

HAL is a multi-disciplinary open access archive for the deposit and dissemination of scientific research documents, whether they are published or not. The documents may come from teaching and research institutions in France or abroad, or from public or private research centers.
L'archive ouverte pluridisciplinaire HAL, est destinée au dépôt et à la diffusion de documents scientifiques de niveau recherche, publiés ou non, émanant des établissements d'enseignement et de recherche français ou étrangers, des laboratoires publics ou privés. 


\title{
Geochemical records of limestone façades exposed to urban atmospheric contamination as monitoring tools?
}

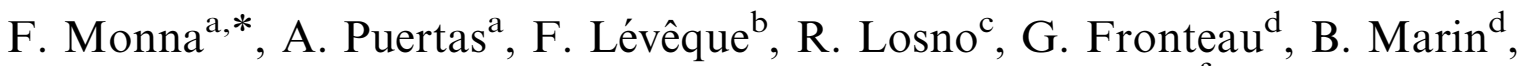

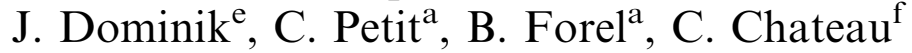 \\ ${ }^{a}$ Centre des Sciences de la Terre, ARTéHIS, UMR 5594 CNRS-Culture, Université de Bourgogne, Bat., Gabriel, F-21000 Dijon, France \\ ${ }^{\mathrm{b}}$ Centre Littoral de Géophysique, Université de La Rochelle, Pôle Sciences et Technologie, Avenue Michel Crépeau, \\ F-17042 La Rochelle, Cedex 01, France \\ ${ }^{\mathrm{c}}$ LISA, Universités Paris 7 et Paris 12, CNRS, Faculté des Sciences, 61 av. du Gal de Gaulle, F-94010 Créteil Cedex, France \\ ${ }^{\mathrm{d}}$ Groupe d'Etudes sur les Géomatériaux et les Environnements Naturels et Anthropiques, EA 3795, Université de Reims Champagne-Ardenne, \\ F-51100 Reims, France \\ ${ }^{\mathrm{e}}$ Institut F.-A. Forel, Université de Genève, 10 route de Suisse, CH-1290, Versoix, Switzerland \\ ${ }^{\mathrm{f}}$ Centre des Sciences de la Terre, Université de Bourgogne, Bat, Gabriel, F-21000 Dijon, France
}

Received 2 July 2007; received in revised form 5 October 2007; accepted 8 October 2007

\begin{abstract}
Magnetic susceptibility, surface rock soiling, elemental composition and lead isotope ratios were measured in surface stone samples collected at different heights of a late 19th century building in Dijon, France. We targeted four limestone façades that differ in orientation and proximity to car traffic. It seems that zinc, copper, sulphur and cadmium are present as diffuse pollutants in urban atmosphere, at least at the scale of the building studied. In contrast, lead and arsenic exhibit point sources: automotive traffic and past coal-burning fly-ash emissions; both coherent with lead isotopic composition measurements. Parameter variations primarily result from exposition to rain washing or micro-scale runoff, and from the closeness, magnitude and origin of anthropogenic sources. Both anthropogenic particles and natural dust tend to be similarly affected by deposition/soiling and rain washing, which act dynamically as competitive processes. Examination of archival photographs suggests that soiling predominated in the past, when the air was rich in black dust, whereas equilibrium or even weathering may occur nowadays due to recent improvements or at least changes in air quality. Using the chemical composition of building façades to provide insights into the magnitude and dispersion of urban atmospheric pollutants may not always be straightforward because of uncertainties related to the period of accumulation.
\end{abstract}

$K$

\section{Introduction}

Monitoring heavy metal pollution levels in the urban atmosphere is of environmental concern because it allows strategies to be developed to identify, and then reduce, the impact of emitting 
sources. Surveys or prospecting studies are often performed by determining airborne particulate matter composition. Such an approach is very convenient but remains costly. Frequent sampling is needed to provide representative information because heavy metal contents in the atmosphere are highly variable and depend on meteorological conditions and diurnal cycles of anthropogenic activity (Flament et al., 2002; Bollhöffer and Rosman, 2002; Haack et al., 2002). Alternatives based on the analysis of biological receptors, such as lichens, pine needles or mosses have been developed in urban areas (e.g. Åberg et al., 1999; Alaimo et al., 2000; Tommasini et al., 2000; Cloquet et al., 2006; Monna et al., 2006) but they are strictly limited by the natural occurrence of the species studied. A more natural approach to investigate urban air pollution would consist in focussing directly on the buildings themselves. Air pollution is known to have a deleterious effect on walls since sulphur dioxide induces the transformation of calcite $\left(\mathrm{CaCO}_{3}\right)$ into gypsum $\left(\mathrm{CaSO}_{4} \cdot 2 \mathrm{H}_{2} \mathrm{O}\right)$ (i.e. Rodriguez-Navarro and Sebastian, 1996; Simão et al., 2006). Gypsum is soluble and tends to crystallise preferentially in areas sheltered from rain (Lefèvre and Ausset, 2002). It incorporates natural dust, soot carbonaceous particles resulting from combustion, and other anthropogenic particles of various origins, which give the deposit its characteristic blackness: the so-called black crust (Galletti et al., 1997; Ausset et al., 1999). The presence of gypsum increases the surface roughness of stones and facilitates the mechanical deposition of particles. Sulfation processes may also be favoured by fly ash.

Our working hypothesis is that stone surfaces of building façades may have retained over time some of the pollution to which they have been subjected, and hence may provide information about the magnitude, dispersion and origin of current and former heavy metal pollution in urban areas. Magnetic and isotopic parameters should help to validate this assumption. High temperature fossilfuel combustion produces magnetic spherules of micronic size associated to heavy metals (Hunt et al., 1984; Hoffman et al., 1999; readers will also find reviews of this topic in Petrovsky and Ellwood, 1999). Magnetic material presents the advantage of being rapidly and accurately measurable, even at low thresholds, thus providing an inexpensive proxy to chart pollution. Various approaches to dust characterisation are described in many recent studies (Lecoanet et al., 2001, 2003; Matzka and
Maher, 1999; Petrovský et al., 2000; Lehndorff et al., 2006; Jordanova et al., 2003; Moreno et al., 2003; Urbat et al., 2004; Sagnotti et al., 2006). Lead isotope ratios are known to be useful tools to determine the origin of lead in various environments if the potential sources are properly characterised by distinct isotopic signatures. More information about fundamentals can easily be found in an abundant literature (e.g. Elbaz-Poulichet et al., 1984; Walraven et al., 1997; Weiss et al., 1999; Hansmann and Köppel, 2000; Takeda et al., 2000).

For this study, geochemical and geophysical (magnetic susceptibility) parameters were measured on samples collected from four front walls of a late 19th century building in Dijon (agglomeration approx. 240000 inhabitants) selected to present contrasting exposition to rain washing and to car traffic. The persistence of geochemical information on building façades is discussed, allowing an evaluation of the extent to which façades can be used to monitor urban atmospheric contamination.

\section{The site}

Carnot College, in the heart of Dijon, was built in 1893 with calcareous materials from open Burgundy quarries (Bathonian/Calovian oolitic and oobioclastic limestones). Four building façades were selected for the present study because of their geographical orientation and their exposition to urban atmospheric pollution (Fig. 1). The first façade, built entirely of calcareous stone, corresponds to the 'Main entrance' of the College. It faces northeast and is directly exposed to one of the busiest streets in Dijon: 22000 cars per day on average (Car traffic regulation office, pers. comm., 2005). Two sets of traffic lights are situated opposite the entrance. The other three façades are located within a $50 \mathrm{~m}$ perimeter radius in a courtyard, inside the school (Fig. 1). They are close to two streets with traffic averaging approximately 5700 and 9600 cars per day (Car traffic regulation office, pers. comm., 2005). These façades are mostly composed of cement rendering, apart from doorway and window frames made of calcareous stones. The darkest façade, namely 'Workshop', faces northeast, while the other two, namely 'Cafeteria/clean' and 'Cafeteria/dirty', belong to the same building and face northwest. The college buildings have not been altered in any way since their construction, except for 'Cafeteria/clean' that was cleaned in 2002 with high-pressure washers. The heating system of the 

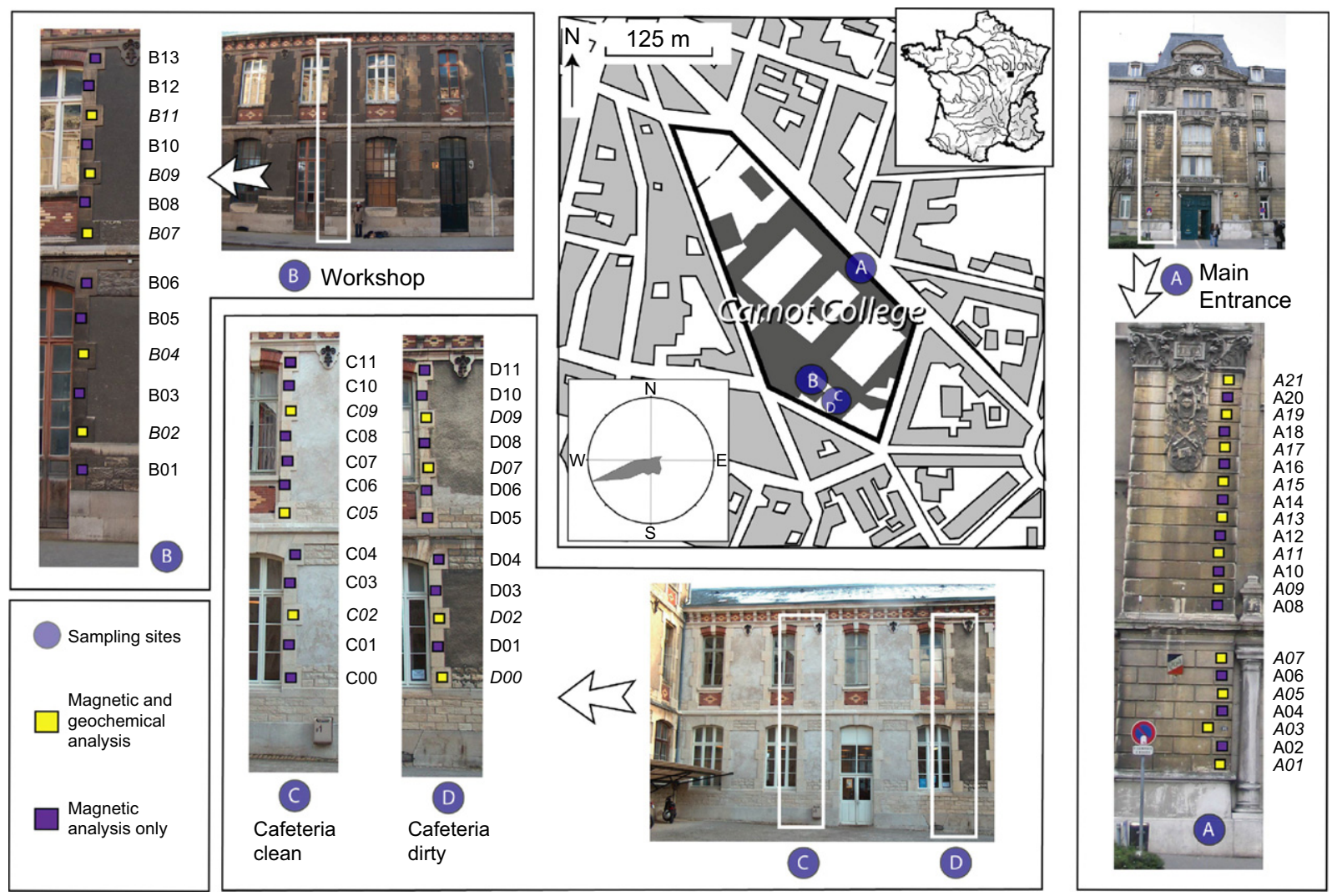

Fig. 1. Map of Carnot College, Dijon. The blue spots represent the targeted façades: 'Main entrance', 'Workshop', 'Cafeteria/clean' and 'Cafeteria/dirty', on which in-situ and laboratory magnetic susceptibility and geochemical analyses (yellow boxes), or only magnetic analyses (blue boxes) have been performed. Sample codes are shown to the right of the façade close-up. The main wind direction when it rains in Dijon $\left(>5 \mathrm{~mm}\right.$ ) is also indicated. In Dijon, the mean annual temperature and the relative humidity are about $10.7{ }^{\circ} \mathrm{C}$ and $71 \%$, respectively. All calculations have been performed on the basis of the 1971-2000 record. (Meteo France, pers. comm., 2007).

college, first coal- and then oil-fired, was installed in the same building as 'Workshop' and smoke exited via the roof.

To sum up, targeted façades may be (i) similarly oriented but differently exposed to car traffic: 'Main entrance' vs. 'Workshop', (ii) similarly exposed to pollution but differently oriented: 'Workshop' vs. 'Cafeteria/dirty', and (iii) similarly exposed and oriented but with different exposure time: 'Cafeteria/ clean' vs. 'Cafeteria/dirty'.

\section{Material and methods}

\subsection{Sampling}

Surface stone samples were collected from calcareous blocks using an aerial work platform. Fine powders were obtained by scratching manually a $20 \times 10 \mathrm{~cm}^{2}$ stone surface with a pre-cleaned (using diluted $\mathrm{HCl}$ and MilliQ water) stainless steel spatula. This operation was carried out as homogeneously as possible by targeting only the external surface of the calcareous blocks. Cement rendering, stonework jointures and any repairs were systematically avoided, as these materials could affect the overall magnetic properties (Bidegain et al., 1999; Gołuchowska, 2001). Powders were kept in precleaned hermetic high-density polyethylene tubes until further analysis. Pristine limestone was also collected by drilling the blocks to a depth of $5 \mathrm{~cm}$. Powder extracted from the first $0.5 \mathrm{~cm}$ was discarded in order to prevent contamination from surface soiling. The drills $(5 \mathrm{~mm}$ diameter) were changed for each sample.

\subsection{Geochemical analysis}

About $100 \mathrm{mg}$ of powder was totally digested in PTFE beakers using a mixture of $\mathrm{HNO}_{3}, \mathrm{HCl}$ and HF of Suprapure ${ }^{\circledR}$ grade (Merck, Germany). 
The beakers were disposed on a hot plate $\left(110^{\circ} \mathrm{C}\right)$ and $\mathrm{HCl}$ was first added to the powder to dissolve the calcium carbonate. After effervescence stopped (after 2-3 min), $\mathrm{HF}$ and $\mathrm{HNO}_{3}$ were added, beakers were covered and left on the plate for $12 \mathrm{~h}$. The solutions were evaporated to dryness, retaken with $\mathrm{HNO}_{3}$, diluted with Milli-Q ${ }^{\mathrm{TM}}$ (Millipore) water. Measurements of elemental concentrations were performed by inductively coupled plasma - atomic emission spectrometer (ICP-AES) (Perkin-Elmer Optima 3000, axial view), equipped with an ultrasonic nebulizer (CETAC). Five blanks and four international standard reference materials (SRMs: PACS1, BCSS1, JSD1 and JSD2) were measured together with samples. Blanks were systematically low in comparison to samples, so that blank correction was never required. The SRM measurements were in good agreement with certified values, approximately $\pm 10-15 \%$. Solutions were also measured for their lead isotopic abundances, i.e. ${ }^{206} \mathrm{~Pb} /{ }^{207} \mathrm{~Pb}$ and ${ }^{208} \mathrm{~Pb} /{ }^{206} \mathrm{~Pb}$ ratios, with a quadrupole (Q)-ICP-MS HP 4500 installed at the F.-A Forel Institute, University of Geneva. More details about measurements, mass bias corrections, operation settings and NBS-981 bracketing can be found elsewhere (Monna et al., 1998, 2000). Precisions are typically of 2-4 and of 3-7 to the third decimal place for the ${ }^{206} \mathrm{~Pb} /{ }^{207} \mathrm{~Pb}$ and ${ }^{208} \mathrm{~Pb} /{ }^{206} \mathrm{~Pb}$ ratios, respectively (at $95 \%$ confidence level).

\subsection{Magnetic analysis}

Before sampling, magnetic susceptibility was measured directly on the four façades using a KT9 Kappameter (Exploranium) hand-held field magnetic susceptibility metre, with a detection limit of $10^{-5}$ SI. Each determination corresponds to the average of 15 individual measurements obtained by shifting the apparatus over the surface of the wall within the operational area $\left(20 \times 10 \mathrm{~cm}^{2}\right)$, so that uncertainty is limited to about $10^{-6}$ SI, when samples present values sufficiently above the detection limit. Magnetic susceptibility of the powders collected by scratching was also measured at the laboratory using a low-field KLY4S Kappabridge (AGICO). Each determination corresponds to 6-12 measurements in order to reach a precision better than $0.2 \times 10^{-6} \mathrm{SI}$. Both empty and powder-filled plastic boxes were measured in this way and weighted for blank correction. Results were finally normalised to powder weight.

\subsection{Evaluation of façade soiling}

Stone blackness was evaluated on the basis of several digital photographs taken before sampling. In order to correct sky reflections or differences in natural light conditions properly, a Kodak grey chart was placed at different heights on the buildings. Colour pictures were first digitally converted to an 8 bit grey scale using Adobe Photoshop CS for Windows. Then both Kodak test chart and operational areas of targeted stones were grey averaged and expressed as percentage of black. The grey values of stones were finally normalised to those of the adjacent Kodak test chart, so that they all became comparable. Precision was evaluated to about $\pm 5 \%$.

\section{Results}

Magnetic susceptibility, soiling (as blackness) and elemental compositions are reported in Table 1. To check if at least one front wall tends to yield larger values than at least one of the others, a KruskalWallis test, used as a non-parametric alternative to the one-way ANOVA, was applied to each variable (Table 2). When the Kruskal-Wallis test appeared to be significant $(\alpha<0.05)$, all pairwise comparisons between groups were then made using the Conover-Inman method (Conover, 1999) implemented in the StatsDirect software. The Conover-Inman procedure corresponds to a Fisher's least significant difference method performed on ranks. The probability of each presumed "non-difference" between groups was reported when the computed $\alpha$ was below 0.05 . When separations of groups were significant, the tendency from the highest to the lowest value was also summarised in Table 2 to make the reading clearer.

Elemental composition and magnetic susceptibility results for 'Main entrance' and 'Workshop' do not exhibit any significant difference, except for $\mathrm{Pb}$ and As. The highest concentrations of lead are found in the 'Main entrance' samples while for arsenic the 'Workshop' values are the highest. Both façades present higher values than 'Cafeteria/clean' and 'Cafeteria/dirty', except for $\mathrm{Zn}$ that is characterised by lower concentrations for the 'Cafeteria/dirty' group alone. Apart from Zn, 'Cafeteria' samples cannot be statistically distinguished. Lead isotopic compositions of surface stone samples vary within a relatively narrow range: ${ }^{206} \mathrm{~Pb} /{ }^{207} \mathrm{~Pb}: 1.14-1.16$, ${ }^{208} \mathrm{~Pb} /{ }^{206} \mathrm{~Pb}$ : $2.10-2.13$ (Table 1). However, surface samples from 'Main entrance' and 'Cafeteria/dirty' 
Table 1

In situ and laboratory magnetic susceptibility, soiling, elemental and isotopic analyses

\begin{tabular}{|c|c|c|c|c|c|c|c|c|c|c|c|c|c|c|}
\hline & $\begin{array}{l}\text { In-situ } \kappa \text { SI } \\
\left(\times 10^{-5}\right)\end{array}$ & $\begin{array}{l}\text { Lab. } \chi \mathrm{m}^{3} \mathrm{~kg}^{-1} \\
\left(\times 10^{-7}\right)\end{array}$ & Soiling (\%) & $\begin{array}{l}\mathrm{Sc} \\
\left(\mu \mathrm{g} \mathrm{g}^{-1}\right)\end{array}$ & $\begin{array}{l}\mathrm{Pb} \\
\left(\mu \mathrm{g} \mathrm{g}^{-1}\right)\end{array}$ & $\begin{array}{l}\mathrm{Cu} \\
\left(\mu \mathrm{g} \mathrm{g}^{-1}\right)\end{array}$ & $\begin{array}{l}\mathrm{Zn} \\
\left(\mu \mathrm{gg}^{-1}\right)\end{array}$ & $\mathrm{Cd}\left(\mu \mathrm{g} \mathrm{g}^{-1}\right)$ & $\mathrm{S}(\%)$ & $\begin{array}{l}\text { As } \\
\left(\mu \mathrm{gg}^{-1}\right)\end{array}$ & ${ }^{206} \mathrm{~Pb} /{ }^{207} \mathrm{~Pb}$ & \pm & ${ }^{208} \mathrm{~Pb} /{ }^{206} \mathrm{~Pb}$ & \pm \\
\hline \multicolumn{15}{|l|}{ Main entrance (ME) } \\
\hline A01 & 3.7 & 4.82 & 69 & 0.67 & 174 & 20 & 113 & 0.18 & 7.0 & 48 & 1.140 & 0.003 & 2.126 & 0.005 \\
\hline A03 & 3.9 & 2.90 & 63 & 0.74 & 155 & 12 & 100 & 0.26 & 7.0 & 62 & 1.141 & 0.003 & 2.121 & 0.005 \\
\hline A05 & 4.1 & 3.48 & 54 & 0.62 & 183 & 14 & 70 & 0.15 & 8.9 & 94 & 1.146 & 0.003 & 2.116 & 0.007 \\
\hline A07 & 4.5 & 5.14 & 54 & 0.77 & 239 & 11 & 58 & 0.27 & 8.1 & 91 & 1.143 & 0.003 & 2.117 & 0.004 \\
\hline A09 & 5.8 & 10.6 & 73 & 1.27 & 348 & 35 & 105 & 0.30 & 9.4 & 118 & 1.148 & 0.004 & 2.118 & 0.007 \\
\hline A11 & 5.6 & 8.43 & 72 & 1.08 & 270 & 24 & 103 & 0.26 & 9.1 & 117 & 1.148 & 0.002 & 2.118 & 0.004 \\
\hline A13 & 5.6 & 7.51 & 72 & 1.04 & 270 & 23 & 94 & 0.34 & 8.9 & 131 & 1.145 & 0.002 & 2.120 & 0.006 \\
\hline A15 & 5.7 & 7.74 & 68 & 1.10 & 309 & 31 & 99 & 0.29 & 8.9 & 116 & 1.140 & 0.003 & 2.127 & 0.005 \\
\hline A17 & 4.9 & 5.42 & 56 & 0.82 & 254 & 20 & 79 & 0.33 & 8.2 & 117 & 1.141 & 0.003 & 2.125 & 0.007 \\
\hline A19 & 4.5 & 4.85 & 50 & 0.78 & 199 & 18 & 73 & 0.32 & 7.8 & 84 & 1.144 & 0.002 & 2.122 & 0.006 \\
\hline A21 & 5.3 & 7.26 & 48 & 0.90 & 254 & 18 & 67 & 0.38 & 8.5 & 112 & 1.150 & 0.004 & 2.116 & 0.007 \\
\hline Average (Std. dev.) & $4.9(0.8)$ & $6.2(2.3)$ & $62(10)$ & $0.9(0.2)$ & $240(60)$ & $21(7)$ & $87(18)$ & $0.28(0.07)$ & $8.3(0.8)$ & $100(26)$ & $1.144(0.004)$ & & $2.121(0.004)$ & \\
\hline \multicolumn{15}{|l|}{ Workshop (W) } \\
\hline B02 & 5.7 & 10.9 & 38 & 1.33 & 151 & 34 & 117 & 0.28 & 9.7 & 39 & 1.158 & 0.002 & 2.105 & 0.006 \\
\hline B04 & 5.4 & 8.54 & 77 & 1.21 & 164 & 23 & 95 & 0.88 & 9.9 & 439 & 1.151 & 0.002 & 2.117 & 0.004 \\
\hline B07 & 7.2 & 10.0 & 71 & 1.12 & 164 & 25 & 128 & 0.62 & 9.8 & 314 & 1.151 & 0.003 & 2.114 & 0.003 \\
\hline B09 & 3.4 & 5.56 & 67 & 0.68 & 65 & 7.9 & 93 & 0.32 & 6.4 & 172 & 1.153 & 0.003 & 2.115 & 0.004 \\
\hline B11 & 4.6 & 3.93 & 53 & 0.68 & 66 & 8.0 & 96 & 0.53 & 6.3 & 205 & 1.149 & 0.002 & 2.115 & 0.006 \\
\hline Average (Std. dev.) & $5.3(1.4)$ & $7.8(3.0)$ & $61(16)$ & $1.0(0.3)$ & $122(52)$ & $20(11)$ & $106(16)$ & $0.53(0.24)$ & $8.4(1.9)$ & $233(151)$ & $1.152(0.003)$ & & $2.113(0.005)$ & \\
\hline \multicolumn{15}{|l|}{ Cafeteria/clean (CC) } \\
\hline $\mathrm{C} 02$ & 2.3 & 0.52 & 48 & 0.43 & 11 & 4.3 & 77 & 0.15 & 0.5 & 6.3 & 1.155 & 0.003 & 2.108 & 0.007 \\
\hline $\mathrm{C} 05$ & 2.9 & 0.36 & 43 & 0.41 & 10 & 3.2 & 193 & 0.02 & 0.4 & 6.5 & 1.150 & 0.003 & 2.110 & 0.007 \\
\hline $\mathrm{C} 09$ & 2.8 & 0.27 & 41 & 0.28 & 5.2 & 2.0 & 130 & 0.03 & 0.3 & $<$ & 1.150 & 0.005 & 2.101 & 0.005 \\
\hline Average (Std. dev.) & $2.7(0.3)$ & $0.38(0.13)$ & $44(4)$ & $0.37(0.08)$ & $8.7(3.1)$ & $3.2(1.2)$ & $133(58)$ & $0.06(0.07)$ & $0.4(0.1)$ & $<5.9(0.8)$ & $1.152(0.003)$ & & $2.106(0.005)$ & \\
\hline \multicolumn{15}{|l|}{ Cafeteria/dirty (CD) } \\
\hline D00 & 2.9 & 0.59 & 55 & 0.54 & 41 & 4.2 & 75 & 0.16 & 0.8 & 40 & 1.143 & 0.002 & 2.118 & 0.004 \\
\hline D02 & 2.5 & 0.26 & 54 & 0.30 & 17 & 2.3 & 31 & 0.10 & 0.3 & 8.9 & 1.142 & 0.003 & 2.119 & 0.008 \\
\hline D07 & 3.3 & 0.33 & 49 & 0.27 & 16 & 1.8 & 34 & 0.03 & 0.2 & $<$ & 1.142 & 0.004 & 2.118 & 0.006 \\
\hline D09 & 2.8 & 0.21 & 43 & 0.28 & 12 & 2.7 & 26 & 0.05 & 0.2 & 7.4 & 1.141 & 0.003 & 2.123 & 0.007 \\
\hline Average (Std. dev.) & $2.9(0.3)$ & $0.35(0.17)$ & $50(6)$ & $0.35(0.13)$ & $22(13)$ & $2.8(1.0)$ & $42(23)$ & $0.09(0.06)$ & $0.4(0.3)$ & $<15(16)$ & $1.142(0.001)$ & & $2.120(0.002)$ & \\
\hline Pristine limestone A & - & 0.11 & - & $<$ & $<$ & 3.8 & 37 & $<$ & 0.2 & $<$ & 1.201 & 0.004 & 2.045 & 0.010 \\
\hline Pristine limestone B & - & 0.09 & - & 0.21 & $<$ & 3.0 & 14 & $<$ & 0.3 & $<$ & - & - & - & - \\
\hline
\end{tabular}

Errors are given at a $95 \%$ confidence level for lead isotopes. For the other parameters, see text. '<': below detection limit; '-': not determined. Detection limits were reported on the basis of concentration in the solid.

To facilitate comparison between façades, and although data are treated using nonparametric statistics, averages and standard deviations are also reported for each façade. 
Table 2

p-Value of the Kruskal-Wallis test

\begin{tabular}{|c|c|c|c|}
\hline & KW test & Conover-Inman test & Summary \\
\hline In situ $\kappa$ & $p=0.003$ & $\mathrm{ME}-\mathrm{CC}(p<0.001) ; \mathrm{ME}-\mathrm{CD}(p<0.001) ; \mathrm{W}-\mathrm{CC}(p<0.001) ; \mathrm{W}-\mathrm{CD}(p<0.001)$ & $\mathrm{ME}-\mathrm{W}>\mathrm{CC}-\mathrm{CD}$ \\
\hline Lab. $\chi$ & $p=0.002$ & $\operatorname{ME}-\mathrm{CC}(p=0.002) ; \mathrm{ME}-\mathrm{CD}(p<0.001) ; \mathrm{W}-\mathrm{CC}(p<0.001) ; \mathrm{W}-\mathrm{CD}(p<0.001)$ & $\mathrm{ME}-\mathrm{W}>\mathrm{CC}-\mathrm{CD}$ \\
\hline Black. $(\%)$ & $p=0.053$ & - & - \\
\hline $\mathrm{Sc}$ & $p=0.002$ & $\operatorname{ME}-\mathrm{CC}(p=0.002) ; \mathrm{ME}-\mathrm{CD}(p<0.001) ; \mathrm{W}-\mathrm{CC}(p<0.001) ; \mathrm{W}-\mathrm{CD}(p<0.001)$ & $\mathrm{ME}-\mathrm{W}>\mathrm{CC}-\mathrm{CD}$ \\
\hline $\mathrm{Pb}$ & $p=0.0003$ & $\begin{array}{l}\text { ME-W }(p<0.001) ; \mathrm{ME}-\mathrm{CC}(p<0.001) ; \mathrm{ME}-\mathrm{CD}(p<0.001) ; \mathrm{W}-\mathrm{CC}(p<0.001) \\
\mathrm{W}-\mathrm{CD}(p=0.02)\end{array}$ & $\mathrm{ME}>\mathrm{W}>\mathrm{CC}-\mathrm{CD}$ \\
\hline $\mathrm{Cu}$ & $p=0.003$ & $\mathrm{ME}-\mathrm{CC}(p=0.001) ; \mathrm{ME}-\mathrm{CD}(p=0.001) ; \mathrm{W}-\mathrm{CC}(p=0.004) ; \mathrm{W}-\mathrm{CD}(p<0.001)$ & $\mathrm{ME}-\mathrm{W}>\mathrm{CC}-\mathrm{CD}$ \\
\hline $\mathrm{Zn}$ & $p=0.02$ & $\mathrm{ME}-\mathrm{CD}(p=0.02) ; \mathrm{W}-\mathrm{CD}(p=0.003) ; \mathrm{CC}-\mathrm{CD}(p=0.002)$ & $\mathrm{ME}-\mathrm{W}-\mathrm{CC}>\mathrm{CD}$ \\
\hline $\mathrm{Cd}$ & $p=0.01$ & ME-CC $(p<0.001) ; \mathrm{ME}-\mathrm{CD}(p=0.001) ; \mathrm{W}-\mathrm{CC}(p<0.001) ; \mathrm{W}-\mathrm{CD}(p<0.001)$ & $\mathrm{ME}-\mathrm{W}>\mathrm{CC}-\mathrm{CD}$ \\
\hline $\mathrm{S}$ & $p=0.002$ & $\mathrm{ME}-\mathrm{CC}(p=0.002) ; \mathrm{ME}-\mathrm{CD}(p<0.001) ; \mathrm{W}-\mathrm{CC}(p=0.002) ; \mathrm{W}-\mathrm{CD}(p<0.001)$ & $\mathrm{ME}-\mathrm{W}>\mathrm{CC}-\mathrm{CD}$ \\
\hline As & $p=0.002$ & $\begin{array}{l}\text { ME-W }(p=0.048) ; \mathrm{ME}-\mathrm{CC}(p<0.001) ; \mathrm{ME}-\mathrm{CD}(p=0.001) ; \mathrm{W}-\mathrm{CC}(p<0.001) \\
\mathrm{W}-\mathrm{CD}(p<0.001)\end{array}$ & $\mathrm{W}>\mathrm{ME}>\mathrm{CC}-\mathrm{CD}$ \\
\hline${ }^{206} \mathrm{~Pb} /{ }^{207} \mathrm{~Pb}$ & $p=0.002$ & $\mathrm{ME}-\mathrm{W}(p<0.001) ; \mathrm{ME}-\mathrm{CC}(p=0.002) ; \mathrm{W}-\mathrm{CD}(p<0.001) ; \mathrm{CC}-\mathrm{CD}(p=0.001)$ & $\mathrm{W}-\mathrm{CC}>\mathrm{ME}-\mathrm{CD}$ \\
\hline
\end{tabular}

If KW-test yielded a $p$-value lower than 0.05 , all pairwise comparisons were made and the probability of each presumed "non-difference" was indicated. When the separation of groups was significant, the tendency from the highest to the lowest value was also summarized: ME for 'Main entrance', W for 'Workshop', CC for 'Cafeteria/clean', CD for 'Cafeteria/dirty'.

appear to be significantly less radiogenic than those originating from 'Workshop' and 'Cafeteria/clean' façades (Table 2). Pristine calcareous fragments are markedly different, with ${ }^{206} \mathrm{~Pb} /{ }^{207} \mathrm{~Pb}$ ratios of 1.201 and ${ }^{208} \mathrm{~Pb} /{ }^{206} \mathrm{~Pb}$ ratios of 2.045 (Table 1), typical of lead naturally present in unpolluted rocks and soils in Western Europe (Shotyk et al., 1998; Semlali et al., 2004).

In a Spearman correlation coefficient matrix (Table 3), in-situ and laboratory magnetic susceptibility, façade blackness, and Al, Sc, Ti, V, Cr, Fe, Co and $\mathrm{Ni}$ (these latter elements are not reported in Table 1 except for Sc) appear to be significantly correlated to one another. Figs. $2 \mathrm{a}$ and $\mathrm{b}$ display soiling vs. in-situ magnetic susceptibility and Fe vs. Sc relationships respectively. The lowest elemental concentrations are generally found in pristine calcareous materials or in 'Cafeteria' samples (Table 1). No clear vertical gradient is observed within each façade.

\section{Discussion}

\subsection{Sampling significance checked using magnetic susceptibility}

Incorporating a variable amount of preserved pristine limestone when scratching soiling from
Table 3

Spearman correlation coefficient matrix between in-situ $\kappa$, lab. $\chi$, soiling and elemental concentrations of $\mathrm{Al}, \mathrm{Sc}, \mathrm{Ti}, \mathrm{V}, \mathrm{Cr}, \mathrm{Fe}, \mathrm{Co}$ and $\mathrm{Ni}$

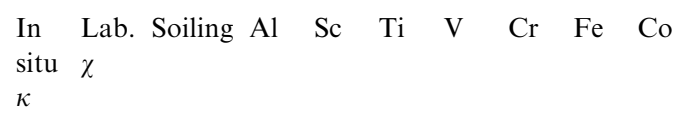

All correlations appear to be significant $(\alpha<0.05)$.

surface stones may lead to variable dilution by deeper and thus cleaner material. As a result, some parameters measured in collected powders may vary together, and hence be intercorrelated, simply because of the dilution effect of this clean material. Scratching homogeneity must therefore be tested prior to any further interpretation of geochemical and magnetic results. As field and laboratory 

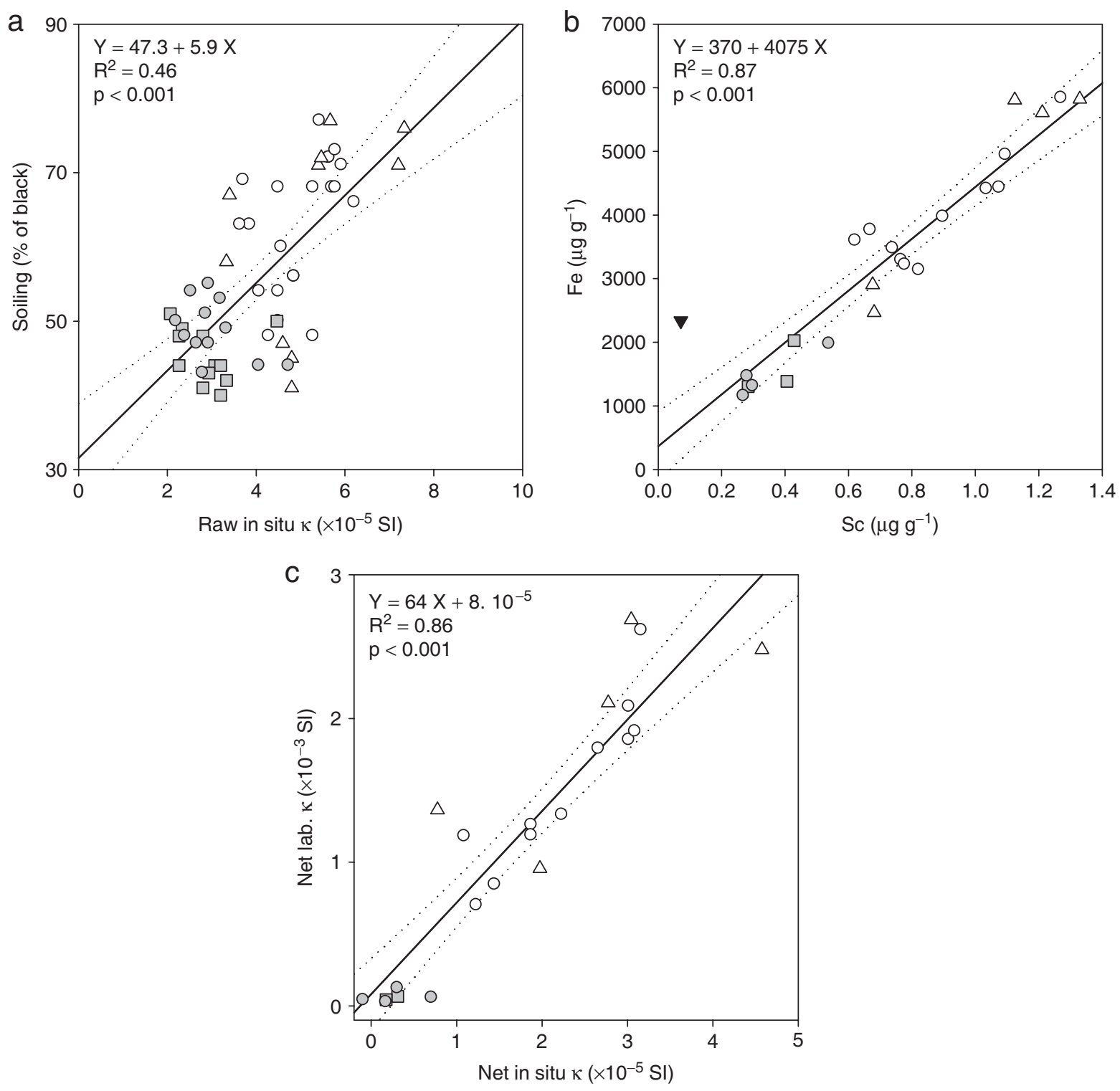

Fig. 2. (a) Soiling vs. Raw in-situ magnetic susceptibility; (b) Sc vs. Fe and (c) net laboratory magnetic susceptibility vs. net in-situ magnetic susceptibility, both corrected by the magnetic susceptibility contribution of pristine limestone (see text for details). Open circles, open triangles, closed boxes and closed circles correspond to 'Main entrance', 'Workshop', 'Cafeteria/clean' and 'Cafeteria/dirty', respectively. Closed triangle represents pristine limestone. Linear regressions and confidence intervals at $95 \%$ confidence level have been computed without taking pristine material into account.

determinations of magnetic susceptibility are normalised by volume and mass respectively, comparisons cannot be straightforward. Field and laboratory values were therefore expressed in the same SI unit and corrected for the contribution from pristine limestone. The new values, called net in-situ and net laboratory magnetic susceptibility, are computed assuming a limestone density value of 2.58 and an average magnetic susceptibility of
$10^{-8} \mathrm{~m}^{3} \mathrm{~kg}^{-1}$; the value measured in drilled samples (Table 1). The strong correlation passing almost through the origin observed between net in-situ and laboratory magnetic susceptibility measurements demonstrate the efficiency of our collection procedure (Fig. 2c). Net laboratory magnetic susceptibility of powders appears to be, on average, almost 65 times higher than net in-situ measurements. The portable KT9 magnetic susceptibility metre takes 
into account not only surface soiling but also a considerable amount of weakly magnetic pristine material to a depth of some centimetres (KT5 estimation in Lecoanet et al., 1999), while KLY4 measurement is carried out on powders which represent a concentrate of magnetic particles.

\subsection{Geochemical record of surface stones}

The normalisation of $\mathrm{Al}, \mathrm{Ti}, \mathrm{V}, \mathrm{Cr}, \mathrm{Fe}, \mathrm{Co}$, and $\mathrm{Ni}$ contents to Sc produces an overall resemblance with the ratios assumed to characterize the upper continental crust (UCC, Fig. 3). This group of elements very probably originates from the calcareous rock itself, or from natural dust particles captured by the buildings, or both. An endogenous origin is privileged for the 'Cafeteria/dirty' and 'Cafeteria/clean' samples since they have approximately the same concentrations as pristine limestone (Table 1). As 'Main entrance' and 'Workshop' samples are generally enriched in lithogenic elements (see Sc, Table 1), an incorporation of exogenous, lithogenic-rich dust is more likely.

All these elements present higher concentrations in 'Main entrance' and 'Workshop' than in 'Cafe- teria' samples. At this point, it is worth recalling that 'Workshop' and 'Main entrance' façades are oriented northeast and are therefore protected from most of the rainy events which, in Dijon, come predominantly from the west or south-west (Fig. 1). The 'Cafeteria' façades are oriented northwest and thus more frequently exposed to rainfall. Interfaçade variability could therefore be primarily due to orientation: natural dust particles deposited on all walls would settle preferably and durably on those sheltered from rain. Noticeable variations also occur at the scale of the façade itself (see all parameters in Table 1). Such intra-façade variability results from well-known micro-scale runoff variations that give façades a patchy appearance. Selective rain washing and variable water runoff within façades are therefore expected to be responsible for the high Spearman correlation coefficients observed between lithogenic elements, but also between this group of elements and magnetic susceptibility or surface soiling (Table 3). However, among all these variables, soiling is the one with the lowest correlation coefficients, which suggests that this parameter is the least related to the abovementioned processes.

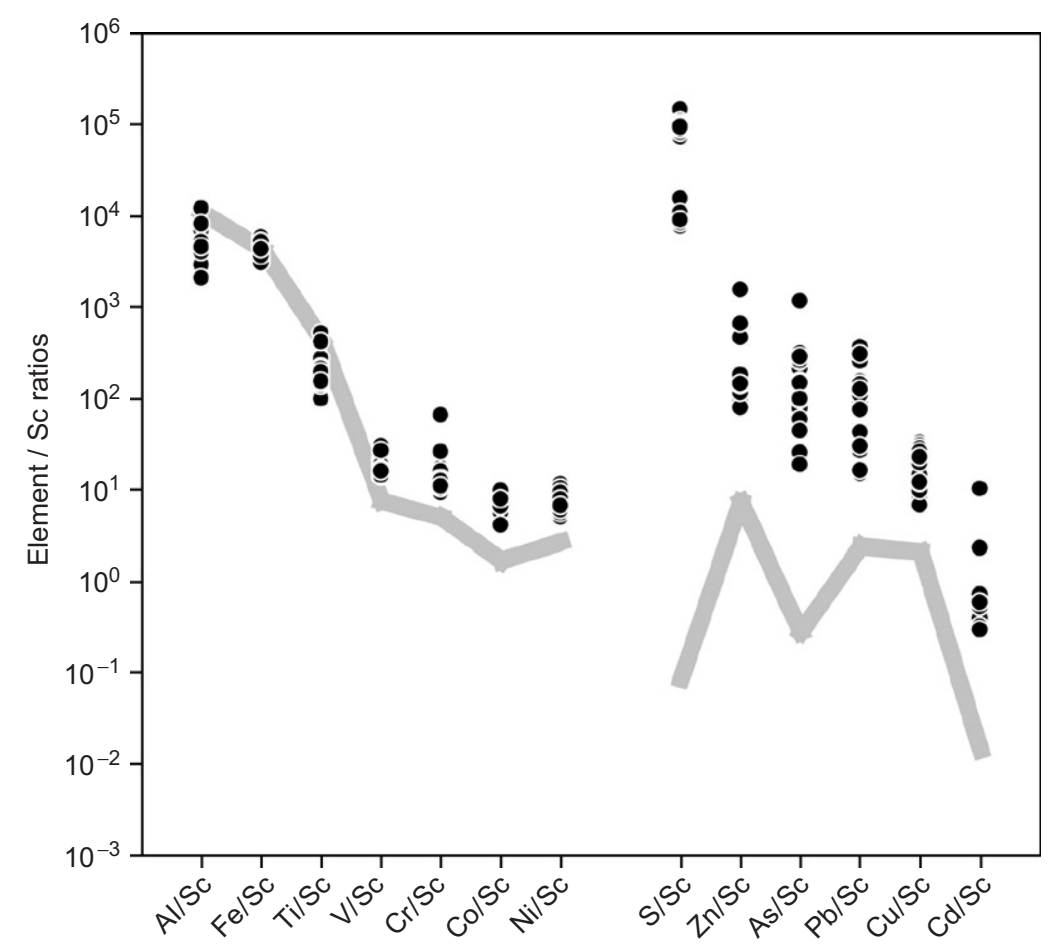

Fig. 3. Elements/Sc ratios in surface stone samples: closed circles. The grey line corresponds to the average values supposed to characterise the upper continental crust (Wedepohl, 1995). 
The $\mathrm{Pb}, \mathrm{Cu}, \mathrm{Zn}, \mathrm{Cd}, \mathrm{S}$ and As contents were also normalised to $\mathrm{Sc}$ and compared to UCC values (Fig. 3) and differences of several orders of magnitude were observed. Although the generalised use in environmental studies of UCC values has been severely and justifiably criticised because they constitute a rough approximation which does not take into account the local variability of natural sources (Reinmann and de Carita, 2000, 2005), the differences are so high in this study that the origin of these elements is undoubtedly anthropogenic. The $\mathrm{Cu}, \mathrm{Cd}$ and $\mathrm{S}$ contents display similar patterns to those of the lithophilic elements: 'Workshop''Main Entrance' > 'Cafeteria' (Table 2). Surprisingly, the 'Cafeteria/clean' samples present high Zn contents, which might perhaps result from cleaning operations in 2002. If these samples are removed from the analysis, the behaviour of $\mathrm{Zn}$ becomes comparable to that of $\mathrm{Cu}, \mathrm{Cd}$ and $\mathrm{S}$, suggesting that particles bearing these elements are retained on the walls similarly to natural particles with respect to rain washing. That would imply diffuse pollution, at least at the scale of the college. The situation for $\mathrm{Pb}$ and $\mathrm{As}$ rather suggests the additional influence of point sources. As leaded gasoline was the major lead contributor to the urban atmosphere over a large part of the 20th century, it is not surprising to find significantly higher $\mathrm{Pb}$ contents in 'Main entrance' samples, in the vicinity of heavy traffic. On the other hand, smoke from the college heating system was, in the past, evacuated from the roof of the 'Workshop' building. The elevated As levels in the 'Workshop' samples might thus be due to the influence of coal and oil combustion products, since fly ash is known to be enriched in arsenic, just as lead is. Lead isotopes could allow this scenario to be explored. Isotopic composition of leaded gasoline is known to have varied from about 1.16 in the late 1960s (Chow and Earl, 1972) to about 1.08-1.10 from the 1980s until the time when lead was definitely phased out from gasoline in France, on 1st January 2000, (Elbaz-Poulichet et al., 1984; Monna et al., 1997; Véron et al., 1999). Nowadays, lead emitted by car exhausts is at the trace level and originates from crude oil. Coal burning is believed to have been an important source before it was replaced by oil combustion for domestic heating. ${ }^{206} \mathrm{~Pb} /{ }^{207} \mathrm{~Pb}$ ratios between 1.16 and 1.18 were measured in coal samples (Walraven et al., 1997) and these values are in good agreement with pollution recorded prior to the $50 \mathrm{~s}$ in archival soil, herbage, or sphagnum moss samples, in France, the
UK and Switzerland (Bacon et al., 1996; Weiss et al., 1999; Semlali et al., 2004). Dijon has never been a major industrial centre. However, it is interesting to recall that ${ }^{206} \mathrm{~Pb} /{ }^{207} \mathrm{~Pb}$ ratios around 1.14-1.16 have often been reported for industrial emissions in France, and more generally in Western Europe, during the 1990s (Monna et al., 1997; Hansmann and Köppel, 2000).

It is clear that the ${ }^{206} \mathrm{~Pb} /{ }^{207} \mathrm{~Pb}$ ratios measured in surface stone samples (1.14-1.16) are incompatible with those of pristine limestone $(\sim 1.205)$, so that several anthropogenic sources must be involved (Table 1; Fig. 4). However, it is not feasible to apportion them accurately as too little information is available about the past evolution of isotopic composition of sources and the integration time of pollutants on to façades. Nonetheless, in the ${ }^{208} \mathrm{~Pb} /{ }^{206} \mathrm{~Pb}$ vs. ${ }^{206} \mathrm{~Pb} /{ }^{207} \mathrm{~Pb}$ diagram, the position of samples from 'Main entrance' tends to be closer to the gasoline domain than those from the 'Workshop' façade that seem to be proportionally more influenced by coal combustion. The 'Main entrance' and 'Cafeteria/dirty' samples present similar isotopic signatures, probably because the latter have also been submitted to direct automotive exhaust fumes from a smaller but adjacent street. The ${ }^{206} \mathrm{~Pb} /{ }^{207} \mathrm{~Pb}$ ratios of the 'Cafeteria/clean' are higher than those of the 'Cafeteria/dirty' façade. Such a finding is quite coherent with many other works dealing with lead isotopes in Western Europe. All these studies indicate that since the reduction and phasing out of lead from gasoline, isotopic signatures of airborne particulate materials tend to become more radiogenic because the relative importance of other sources increases (Grousset et al., 1994; Monna et al., 1997; Bollhöffer and Rosman, 2001; Widory et al., 2004). In any case, the significant isotopic discrepancies observed between the four façades confirm the varying influence of two or more local sources at the scale of the college.

No vertical gradient in lead concentrations or in isotopic compositions is observed at the façade scale, suggesting an intense atmospheric swirl at least as high as the building. In such an urban environment, people living on the second floor would be no less submitted to car pollution than those living on the ground floor. For this reason, even if horizontal variability at the façade scale has not been formally checked, it is logical to suppose that it is low in comparison with inter-façade variability discussed above. Etymezian et al. (1998) 


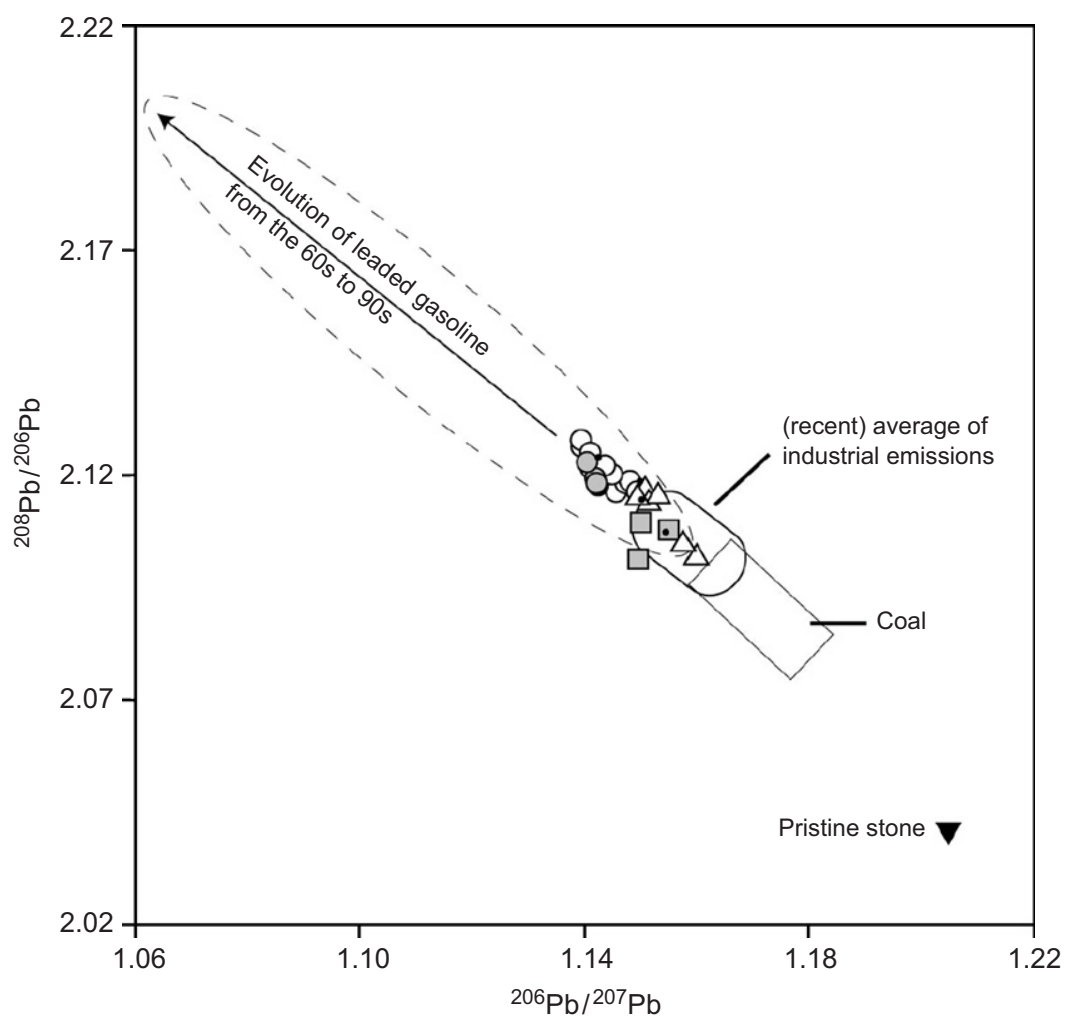

Fig. 4. ${ }^{206} \mathrm{~Pb} /{ }^{207} \mathrm{~Pb}$ vs. ${ }^{208} \mathrm{~Pb} /{ }^{206} \mathrm{~Pb}$ diagram. Open circles, open triangles, closed boxes and closed circles correspond to 'Main entrance', 'Workshop', 'Cafeteria/clean' and 'Cafeteria/dirty' respectively. Closed triangle represents pristine limestone. Potential lead sources are reported for comparative purposes, see text for details.

already noticed at the Cathedral of Learning in Pittsburgh, a much taller building, that airborne concentrations of sulphate and carbon particles were invariant with height. As in our case, soiling patterns were also ascribed to the competitive dynamic processes of pollutant deposition and rain washing. Photographs of the Cathedral from the 1930s showed a much greater amount of soiling than pictures taken recently, as air pollution levels, such as $\mathrm{SO}_{2}$ and fly-ash concentrations, were higher in the past. Similar observations can be made by comparing old postcards of the college with recent photographs (Fig. 5). The 'Main entrance' façade experienced heavy soiling in its early years as demonstrated by the rapid soiling between 1908 and the late 1930s. Between the late 1930s and nowadays, soiling of limestone did not notably progress, and may even have regressed. As reported by Etymezian et al. (1998) in other circumstances, the rate of removal of soiling material by rain was probably equal or greater than the rate of soiling by pollutant deposition and chemical precipitation.

\section{Conclusions}

Our results demonstrate that lithogenic and anthropogenic elements have been deposited, and retained by the surface of the façades to some extent. Comparing in-situ and lab magnetic susceptibility is a reliable parameter to check the efficiency of the collection procedure. Cadmium, copper, sulphur and zinc are present as diffuse pollutants in the urban atmosphere, at least at the scale of the college, while lead and arsenic exhibit point sources: traffic, and coal and oil combustion. Building façades therefore conserve traces of atmospheric memory, but these may fade through exposure to rain washing or micro-scale runoff; both anthropogenic and natural particles being subject to dynamic competition between deposition/precipitation and cleaning by rain as suggested by archival photographs. Despite these difficulties, building façades can be profitably used as monitoring tools provided that certain constraints are observed: (i) exposure to rain should be minimal; (ii) buildings should be of similar age; (iii) the geochemical 

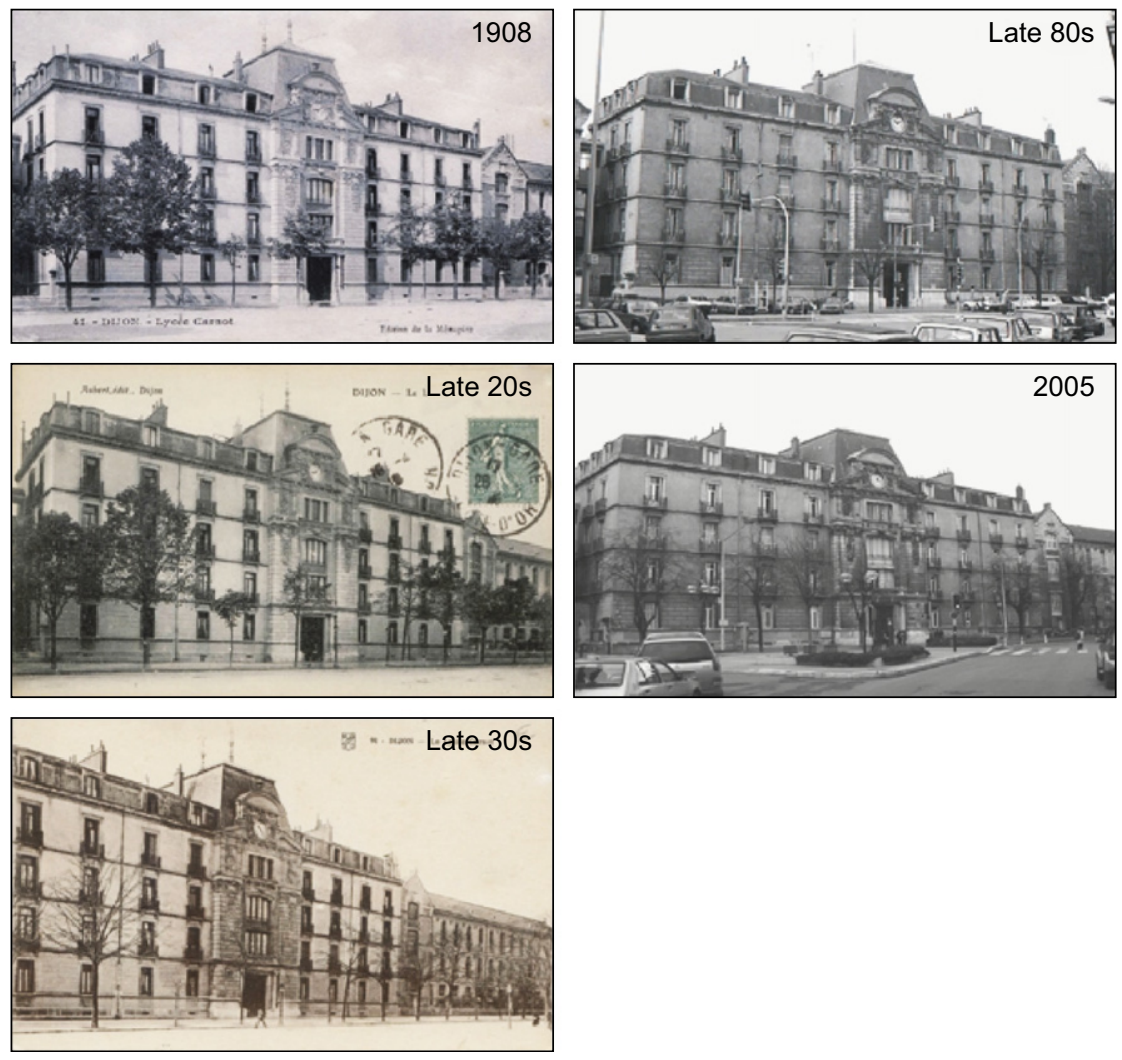

Fig. 5. Archival photographs of Carnot College, main entrance. Dates for postcards are estimated on the basis of the stamp or postage date.

background of construction material should be as low as possible.

\section{Acknowledgements}

We express our gratitude to the city council of Dijon, which generously provided the aerial work platform and to the very kind employees of the city council for their precious assistance in sampling. We also appreciate the help provide by staff at the car traffic regulation office and at Carnot College. M. Mathon and D. Thévenin (Météo France) are also thanked for providing pictures and meteorological data, respectively. We are grateful to C. Durlet for thought-provoking discussions and two anonymous reviewers who improved the manuscript by their judicious comments.

\section{References}

Åberg, G., Pacyna, J.M., Stray, H., Skjelkvåle, .B.L., 1999. The origin of atmospheric lead in Oslo, Norway, studied with the use of isotopic ratios. Atmospheric Environment 33, 3335-3344.

Alaimo, M.G., Dongarrà, G., Melati, M.R., Monna, F., Varrica, D., 2000. Recognition of environmental trace metal contamination using pine needles as bioindicators. The urban area of Palermo (Italy). Environmental Geology 39, 914-924.

Ausset, P., Del Monte, M., Lefèvre, R.A., 1999. Embryonic sulphated black crusts on carbonate rocks in atmospheric simulation chamber and in the field: role of carbonaceous fly ash. Atmospheric Environment 33, 1525-1534.

Bacon, J.R., Jones, K.C., McGrath, S.P., Johnston, A.E., 1996. Isotopic character of lead deposited from the atmosphere at a grassland site in the United Kingdom since 1860. Environmental Science and Technology 30, 2511-2518.

Bidegain, J.C., Sinito, A.M., Rodriguez, M.E., 1999. Remanent magnetization in Portland-cement-based materials. Studia Geophysica et Geodaetica 43, 289-302.

Bollhöffer, A., Rosman, K.J.R., 2001. Lead isotopic ratios in European atmospheric aerosols. Physics and Chemistry of Earth, Part B 26, 835-838.

Bollhöffer, A., Rosman, K.J.R., 2002. The temporal stability in lead isotopic signatures at selected sites in the Southern and Northern hemispheres. Geochimica et Cosmochimica Acta 66, 1375-1386.

Chow, T.J., Earl, J.L., 1972. Lead isotopes in North American coals. Science 176, 510-511. 
Cloquet, C., Carignan, J., Libourel, G., 2006. Atmospheric pollutant dispersion around an urban area using trace metal concentrations and $\mathrm{Pb}$ isotopic compositions in epiphytic lichens. Atmospheric Environment 40, 574-587.

Conover, W.J., 1999. Practical Non-parametric Statistics, third ed. Wiley, New York, 584pp.

Elbaz-Poulichet, F., Holliger, P., Huang, W.W., Martin, J.M., 1984. Lead cycling in estuaries, illustrated by the Gironde estuary, France. Nature 308, 409-414.

Etymezian, V., Davidson, C.I., Finger, S., Striegel, M.F., Barabas, N., Chow, J.C., 1998. Vertical gradients of pollutant concentrations and deposition fluxes on a tall limestone building. Journal of American Institute for Conservation 37, $187-210$.

Flament, P., Bertho, M.-L., Deboudt, K., Véron, A., Puskaric, E., 2002. European isotopic signatures for lead in atmospheric aerosols: a source apportionment based upon ${ }^{206} \mathrm{~Pb} /{ }^{207} \mathrm{~Pb}$ ratios. The Science of the Total Environment 296, 35-57.

Galletti, G., Bochini, P., Cam, D., Chiavari, G., Mazzeo, R., 1997. Chemical characterization of the black crust present on the stone central portal of St. Denis abbey. Fresenius Journal of Analytical Chemistry 357, 1211-1214.

Gołuchowska, B.J., 2001. Some factors affecting an increase in magnetic susceptibility of cement dusts. Journal of Applied Geophysics 48, 103-112.

Grousset, F.E., Quetel, C.R., Thomas, B., Buat-Menart, P., Donard, O.F.X., Bucher, A., 1994. Transient Pb isotopic signatures in the Western-European atmosphere. Environmental Science and Technology 28, 1605-1608.

Haack, U., Gutsche, F.H., Plessow, K., Heinrichs, H., 2002. On the isotopic composition of $\mathrm{Pb}$ in cloud waters in Central Germany. A source discrimination study. Water, Air and Soil Pollution 139, 261-288.

Hansmann, W., Köppel, V., 2000. Lead-isotope as tracers of pollutants in soils. Chemical Geology 171, 123-144.

Hoffman, V., Knap, M., Appel, E., 1999. Magnetic susceptibility mapping of roadside pollution. Journal of Geochemical Exploration 66, 313-326.

Hunt, A., Jones, J., Oldfield, F., 1984. Magnetic measurements and heavy metals in atmospheric particulates of anthropogenic origin. The Science of the Total Environment 33, 129-139.

Jordanova, N., Jordanova, D., Veneva, L., Yorova, K., Petrovsky, E., 2003. Magnetic response of soils and vegetation to heavy metal pollution - a case study. Environmental Science and Technology 37, 4417-4424.

Lecoanet, H., Lévêque, F., Segura, S., 1999. Magnetic susceptibility in environmental applications: comparison of field probes. Physics of the Earth and Planetary Interiors 115, 191-204.

Lecoanet, H., Lévêque, F., Ambrosi, J.-P., 2001. Magnetic properties of salt-marsh soils contaminated by iron industry emissions (southeast France). Journal of Applied Geophysics 48, 67-81.

Lecoanet, H., Lévêque, F., Ambrosi, J.-P., 2003. Combination of magnetic parameters: an efficient way to discriminate soilcontamination sources (south France). Environmental Pollution 122, 229-234.

Lefèvre, R.A., Ausset, P., 2002. Atmospheric Pollution and Building Materials: Stone and Glass. Natural Stone, Weathering Phenomena, Conservation Strategies and Case studies.
Special Publications, vol. 205. Geological Society, London, pp. 329-345.

Lehndorff, E., Urbat, M., Schwark, L., 2006. Accumulation histories of magnetic particles on pine needles as function of air quality. Atmospheric Environment 40, 7082-7096.

Matzka, J., Maher, B.A., 1999. Magnetic biomonitoring of roadside tree leaves: identification of spatial and temporal variations in vehicle-derived particles. Atmospheric Environment 33, 4565-4569.

Monna, F., Lancelot, J., Croudace, I.W., Cundy, A.B., Lewis, J.T., 1997. $\mathrm{Pb}$ isotopic composition of airborne particulate material from France and the Southern United Kingdom: implications for $\mathrm{Pb}$ pollution sources in urban areas. Environmental Science and Technology 31, 2277-2286.

Monna, F., Loizeau, J.-L., Thomas, B.A., Guéguen, C., Favarger, P.-Y., 1998. $\mathrm{Pb}$ and $\mathrm{Sr}$ isotope measurements by inductively coupled plasma-mass spectrometer: efficient time management for precise improvement. Spectrochimica Acta B 59/09, 1317-1333.

Monna, F., Loizeau, J.-L., Thomas, B., Guéguen, C., Favarger, P.-Y., Losno, R., Dominik, J., 2000. Noise identification and sampling frequency determination for precise isotopic measurements by quadrupole-based inductively coupled plasma mass spectrometry. Analusis 28, 750-757.

Monna, F., Poujol, M., Losno, R., Dominik, J., Annegarn, H., Coetzee, H., 2006. Origin of atmospheric lead in Johannesburg, South Africa. Atmospheric Environment 40 , 6554-6566.

Moreno, E., Sagnotti, L., Winkler, A., Dinarès-Turell, J., Cascella, A., 2003. Biomonitoring of traffic air pollution in Rome using magnetic properties of tree leaves. Atmospheric Environment 37, 2967-2977.

Petrovsky, E., Ellwood, B.B., 1999. Magnetic monitoring of air-, land-, and water-pollution. In: Maher, B.A., Thompson, R. (Eds.), Quaternary Climates, Environments and Magnetism. Cambridge University Press, Cambridge, pp. 279-322 (Chapter 8).

Petrovský, E., Kapička, A., Jordanova, N., Knap, M., Hoffmann, V., 2000. Low-field magnetic susceptibility: a proxy method of estimating increased pollution of different environmental systems. Environmental Geology 39, 312-318.

Reinmann, C., de Carita, P., 2000. Intrinsic flaws of element enrichment factors (EFs) in environmental geochemistry. Environmental Science and Technology 34, 5084-5091.

Reinmann, C., de Carita, P., 2005. Distinguishing between natural and anthropogenic sources for elements in the environment: regional geochemical surveys versus enrichment factors. Science of the Total Environment 337, 91-107.

Rodriguez-Navarro, C., Sebastian, E., 1996. Role of particulate matter from vehicle exhaust on porous building stones (limestone) sulfation. The Science of the Total Environment 187, 79-91.

Sagnotti, L., Macri, P., Egli, R., Mondino, M., 2006. Magnetic properties of atmospheric particulate matter from automatic air sampler stations in Latium (Italy): toward a definition of magnetic fingerprints for natural and anthropogenic PM10 sources. Journal of Geophysical Research 111, B12S22.

Semlali, R.M., Dessogne, J.-B., Monna, F., Bolte, J., Azimi, S., Navarro, N., Denaix, L., Loubet, M., Chateau, C., van Oort, F., 2004. Modeling lead input and output in soils using lead isotopic geochemistry. Environmental Science and Technology $38,1513-1521$. 
Shotyk, W., Weiss, D., Appleby, P., Cherbukin, A., Frei, R., Gloor, M., Kramer, J., Reese, S., Van der Knaap, W., 1998. History of atmospheric lead deposition since $12,370{ }^{14} \mathrm{C}$ yr BP from a peat bog, Jura Mountains, Switzerland. Science 281, 1635-1640.

Simão, J., Ruiz-Agudo, E., Rodriguez-Navarro, C., 2006. Effects of particulate matter from gasoline and diesel vehicle exhaust emissions on silicate stones sulfation. Atmospheric Environment 40, 6905-6917.

Takeda, K., Marumoto, K., Minamikawa, T., Sakugawa, H., Fujiwara, K., 2000. Three-year determination of trace metals and the lead isotope ratio in rain and snow depositions collected in Higashi-Hiroshima, Japan. Atmospheric Environment 34, 4525-4535.

Tommasini, S., Davis, G.R., Elliott, T., 2000. Lead isotope composition of tree rings as bio-geochemical tracers of heavy metal pollution: a reconnaissance study from Firenze, Italy. Applied Geochemistry 15, 891-900.

Urbat, M., Lehndorff, E., Schwark, L., 2004. Biomonitoring of air quality in Cologne conurbation using pine needles as a passive sampler-part I: magnetic properties. Atmospheric Environment 38, 3781-3792.

Véron, A., Flament, P., Bertho, M.-L., Alleman, L., Flegal, R., Hamelin, B., 1999. Isotopic evidence of pollutant lead sources in Northwestern France. Atmospheric Environment 33, 3377-3388.

Walraven, N., van Os, B.J.H., Klaver, G.Th., Baker, J.H., Vriend, S.P., 1997. Trace element concentrations and stable lead isotopes in soils as tracers of lead pollution in Graft-De Rijb in Netherlands. Journal of Geochemical Exploration 59, 47-58.

Wedepohl, K.H., 1995. The composition of the crust. Geochimica et Cosmochimica Acta 59, 1217-1232.

Weiss, D., Shotyk, W., Kramers, J.D., Gloor, M., 1999. Sphagnum mosses as archives of recent and past atmospheric lead deposition in Switzerland. Atmospheric Environment 33, 3751-3763.

Widory, D., Roy, S., Le Moullec, Y., Goupil, G., Cocherie, A., Guerrot, C., 2004. The origin of atmospheric particles in Paris: a view through carbon and lead isotopes. Atmospheric Environment 38, 953-1061. 